\title{
Obama, Trump and US politics and diplomacy towards Asia
}

\author{
Robert Sutter
}

\section{Introduction}

As both candidate and throughout his first two years as president to early 2019, Donald Trump employed unilateral actions and flamboyant posturing in upending the strong commitment to positive diplomacy and political engagement of regional governments and organisations of the previous administrations of Barack Obama. Two years into his presidential term, Trump remained avowedly unpredictable as he junked related policy transparency, carefully measured responses, and avoidance of dramatic action, linkage or spill-over among competing interests that characterised Obama government diplomacy.

On the one hand, his approach had the advantage of keeping opponents (like China) as well as allies and partners on the defensive in dealing with the new President. Trump came to see the wisdom of abandoning his earlier cavalier treatment of allies Japan, South Korea and Australia. He built cordial personal ties with most important regional leaders. On the other hand, American engagement in the region remained episodic, featuring intense pressure beginning in 2017 to prevent North Korea's nuclear weapons development and strong actions in 2018 on trade disputes with China that widely impacted other states. Drift characterised his dealing with most other issues. That the President used the pressure to conclude deals with opponents advantageous to the United States seemed to explain his abrupt acceptance of a summit meeting with North Koreas leader and the Trump government's ongoing negotiations with China as it applied tariffs and investment restrictions punishing Beijing. ${ }^{1}$

The administration laid out a dark view of the world in authoritative documents calling for a well-integrated strategy that saw economic, diplomatic and other international strengths as important to overall American national security. China and Russia were the leading opponents. The Trump government followed through with an increase in the defence budget along with strong action defending America 
from predatory trade and investment from China. The administration's remarkable pragmatism on human rights issues showed that the American leadership would not allow these issues to complicate the pursuit of broadly defined elements of American national strategy. Remaining unpredictable, President Trump rarely used the language of the published strategies and continued cordial interchange with the Russian and Chinese leaders.

\section{Trump versus Obama: Diplomacy in Asia}

Soon after taking power in January 2017, the Trump administration unceremoniously announced the end of the Obama administration's signature "Rebalance" policy in Asia. ${ }^{2}$ Launched in 2011, that multifaceted policy was widely welcomed in Asia except notably by China, which took assertive and expansive actions in response that the Obama government was less than successful in countering.

The Rebalance policy accompanied US military pullbacks from Iraq and Afghanistan, with greater attention to a broad range of countries in Asia from India in the west, to Japan in the northeast, to the Pacific Island states in the southeast. US diplomatic activism increased; existing, substantial military deployments were maintained and strengthened in some areas; and trade and investment remained open and were poised to increase, notably via the Trans-Pacific Partnership (TPP), a twelve-nation Asia Pacific economic pact that represented the centrepiece of the economic dimension of the Obama administration's Rebalance policy in Asia. ${ }^{3}$

After assuming leadership in 2012, President Xi Jinping showed a much bolder and more assertive posture than previous Chinese leaders in pursuing its interests in Asia and elsewhere at odds with American interests. Xi used economic enticements on the one hand and coercive and intimidating means short of direct military force on the other hand, to compel neighbours to accept Chinese claims to disputed territories and to side with Beijing against American foreign policy initiatives.

President Obama and his administration representatives maintained that their carefully measured, transparent and moderate responses to China's challenges throughout their time in office led to successful outcomes that reflected well on their historical legacy. They were particularly pleased with US-China agreements on such important global issues as climate change. In contrast, a hardening of opinion about China's growing challenges among mainstream US foreign policy elites showed in the 2016 election campaigns, and across a variety of think tank studies and media commentary. Obama's approach appeared too reactive and solicitous towards China. It was viewed to allow Beijing to repeatedly advance in coercive and illegal ways at the expense of others, notably the United States, without appropriate reprisal. 
Indeed, President Obama's frustrations grew with China's expansionism and "bullying" in disputed maritime areas such as the South China Sea; cyber theft of US economic and industrial property and other grossly unfair economic practices; continued support for North Korea as it flagrantly violated international sanctions and endangered South Korea and neighbouring states; and other matters. Obama broke with his practice of avoiding negative public comments about China in the first six years of his administration, and in 2014 began to more frequently complain about Beijing's infractions.

$\mathrm{Xi}$ Jinping largely ignored the complaints. After many strident warnings, the Obama government eventually took some actions, notably on cyber theft and Chinese bullying and expansionism in the South China Sea. But they were each treated in transparent and measured ways that signalled to Beijing US intent to avoid broader negative consequences for China or US-China relations. The results were mixed; widely publicised offensive Chinese behaviour in the South China Sea and other egregious challenges appeared to meet with an ineffective US response, which American and regional critics saw weakening the US position in the region. ${ }^{4}$

The complaints against the Obama government's ineffectiveness against Chinese challenges fed into a much broader American debate on foreign policy leading up to the 2016 presidential election campaign. Republican leaders in Congress and supporting think tanks and interest groups joined media and other commentators in depicting major shortcomings in the Obama government's policies in Europe, the Middle East and Asia. One target was the so-called Obama Doctrine laid out in the President's speech to graduating West Point cadets in 2014 that showed greater administration wariness regarding security engagements abroad. ${ }^{5}$

In Asia, congressional and other American critics of Obama's Rebalance claimed that Washington was not resolute enough in defending the United States' regional role as security guarantor, and not active enough in promoting greater American trade, investment and diplomatic engagement in competition with China's statedirected efforts. The Republican-leaning Heritage Foundation summed up the critics' concerns by offering far-reaching political-security recommendations for Asia. They included more robust military spending to allow for a long-term goal of 350 naval ships (there are now about 280 ships in the Navy); increased support for allies and partners; expanded involvement with the Association of South East Asian Nations (ASEAN) and other regional groups; and greater firmness in dealing with Chinese challenges to regional and American interests. ${ }^{6}$

\section{Asia, candidate Trump, and 2016 election debates}

Most of the 2016 US presidential candidates talked about eroding or challenged US international power and influence, and the need to reaffirm America's role in the world. Candidates Hillary Clinton, Ted Cruz, John Kasich, Marco Rubio 
and Donald Trump in varying ways favoured strengthening American power and leadership. Bernie Sanders favoured less muscular approaches than the other candidates, emphasising negotiations over military means and pressure. Most advocated strengthened relations with allies, without much emphasis on greater reciprocity on their part.

On specific issues involving US leadership, John Kasich joined free trade advocates in Congress like House Speaker Paul Ryan to support the TPP. Clinton, Cruz, Sanders and Trump voiced varying opposition to the trade pact, but Trump was alone in insisting that allies do more to offset American costs in maintaining their security and overall regional stability or face American withdrawal. He also accepted the possibility that, without support from Washington, allies like Japan and South Korea might be compelled to develop nuclear weapons to protect themselves. All the candidates agreed with overwhelming majorities in Congress that pressure should be applied, including on Beijing, to see a denuclearised North Korea. Yet Trump was alone in also calling for direct talks with North Korea’s Kim Jong-un.

China remained the main country of concern regarding challenging US leadership in Asia. Relevant election discourse focused on how China was an unfair partner, and how the United States needed to counter negative features of its rise. Clinton, Rubio and Cruz argued for greater firmness against Beijing, with Clinton and Rubio advocating tougher specific policies, and Cruz favouring a more robust overall approach. In contrast, Sanders urged negotiations. So did Trump, though he also favoured military build-up and large trade sanctions if needed. ${ }^{7}$

Concern with China remained active throughout the campaigns, but secondary within the rhetoric about Asia. China as an issue was overshadowed by strong debate on international trade and the proposed TPP, and on Trump's controversial proposals on allied burden sharing, nuclear weapons proliferation and North Korea. Trump's strong opposition to the TPP and other US trade efforts was at odds with the free trade policies favoured by Republican congressional leaders, but his position had strong appeal among both Republican and Democratic voters. He and Sanders reinforced each other's arguments, and both rode the surprise wave of populist discontent over globalisation to unexpected success in the primaries. Clinton, Cruz and others reversed or modified their positions to accord with the changed politics surrounding the TPP.

Candidate Trump's unique emphasis on getting Japan, South Korea and other allies to compensate the United States for its role as regional security guarantor prompted serious negative reactions that promised significant complications for US alliance relations in the event of his election as president. His calls for Japan and South Korea to compensate the United States for security support it provided were at odds with proposals by Speaker Ryan, Senator John McCain and other Republican congressional leaders, as well as many Republican-leaning think 
tanks and media. Some of these congressional Republicans vocally opposed such policies.

Trump's acceptance of Japan or South Korea developing nuclear weapons for self-defence, following a US pullback, was a major departure from long-standing policies of Republican and Democratic governments, and one widely seen to add to the danger of war in Northeast Asia. His abrupt announcement that he would seek direct talks with North Korea's leader undermined existing American, South Korean and Japanese policy. It also deviated sharply from the tough posture favoured by the Obama government and by Republican and Democratic congressional leaders and rank and file. ${ }^{8}$ Ultimately, these three sets of controversial proposals by Trump garnered little support in the United States and prompted opposition, including from prominent congressional Republicans.

Meanwhile, candidate Trump's flamboyant and often vulgar campaign attacks were widely seen as diminishing American authority abroad, prompting concern from foreign policy specialists within the United States. His populist appeal came from a style of campaigning that featured repeated personal attacks, gross language, and salacious accusations which degraded America's image, providing fodder for Chinese and other opinion stressing the weaknesses of US democracy. ${ }^{9}$

On policy issues, the success of the Sanders and Trump campaign attacks on the TPP surprised congressional leaders, along with most American and Asian commentators. Their success underlined seemingly weak popular support for this important component of US policy in the region, which Ryan, McCain and other Republican congressional leaders continued to back. The fact that the Republican Party - widely seen in the region as strongly committed to US defence ties with Asia - selected Trump despite his controversial views on military disengagement from Asia and Europe, and his acceptance of nuclear proliferation, raised serious doubts about America’s future regional role.

Among Asian countries dependent on military support from the United States, non-governmental Japanese commentators seemed the most concerned. On the other side of the spectrum, Chinese commentators saw opportunities for leadership gains in competition with the United States in Asia, following the election's negative impact on the credibility of regional American commitment. This development reinforced the determination of Senator McCain and a large bipartisan group of colleagues to travel to the region prior to the election to reassure allies and partners of continued US support. ${ }^{10}$

\section{President Trump’s policies and practices in Asia}

President Trump in 2017 came to see the need for altering his policies towards allies and joining congressional and other leaders in pressuring North Korea on nuclear weapons proliferation. However, his overall approach to Asian and other 
international diplomacy - what New York City police detectives would call his mode of operation - continued to feature dramatic and often crude initiatives that were hard to predict and that raised international tensions, with himself at the centre of attention. The United States is a superpower with many powerful levers of possible use in seeking international advantage. Across his first two years in office it became clear that Trump was much more likely than the more measured and predictable Obama to use those levers in surprising ways, notably by linking issues, and using one source of power in one issue area to gain advantages in another area of policy concern. Whereas the Obama government seemed to prioritise carefully managing differences and resulting tensions, President Trump sought advantage in stoking tensions and exacerbating differences in diplomacy in Asia and beyond. Such behaviour mimicked the controversial and unconventional behaviour of his remarkable and unexpected presidential election victory against more experienced "Establishment" political candidates.

Early Trump administration initiatives upset regional stability, complicating the foreign policies of Asian partners and opponents alike, including China. Subsequent pragmatic summitry eased regional anxiety and clarified the new government's security and political objectives. An effective American strategy remained elusive, especially because of deep divisions in the American administration on trade and economic policy. In 2018, tariffs and restrictions on Chinese investments showed a harder line compatible with an overall toughening of diplomacy, consistent with the administration's National Security Strategy (NSS) and National Defense Strategy (NDS).${ }^{11}$ However, they were implemented along with concurrent high-level negotiations with China to reach a compromise over trade and other economic differences. ${ }^{12}$

There was considerable domestic support, notably in Congress, for the new President's security plans which were generally in line with the priorities of Republican congressional leaders stressing the need to reinforce the American military presence in the region. The omnibus spending bill signed by the President in March 2018 included the first instalment of a planned increase of US $\$ 160$ billion in defence spending over two years, to improve US military readiness and advance its capabilities in the Asia Pacific and other key theatres of operations. ${ }^{13}$

The President's personal engagement with Chinese and other Asian leaders between 2017 and 2019 detailed below was generally supported in Congress. As discussed shortly, few public complaints were seen in Congress, albeit more in the media and among concerned interest groups, about the new US government's reduced emphasis on human rights and good governance in high-level meetings with Asian leaders. Congress generally supported the efforts by Republican congressional leader, and later Vice President, Mike Pence and other administration leaders including Defense Secretary James Mattis, National Security Advisor H. R. McMaster, and Secretary of State Rex Tillerson to steer President Trump towards supporting US alliance relationships with Japan, South Korea, Australia 
and others, which had been seriously questioned by Trump when presidential candidate. The turnover in senior administration leaders, with Tillerson, McMaster and Mattis leaving in 2018 and being replaced by proponents of a harder line in US foreign policy, notably Mike Pompeo and John Bolton, raised congressional concern about the absence of senior administration leaders prepared to moderate Trump's inclinations for more aggressive American diplomacy.

Congress remained overwhelmingly supportive of greater US pressure on North Korea, including on China to help manipulate the policies of Pyongyang. Thus, there was little objection to the high priority the President and his staff gave to responding to North Korean weapons tests. North Korean missile launches increased in frequency in 2017, before slowing dramatically in late 2018, and in that time showed recently unprecedented demonstrations of military power and resolve. The tension featured strident rhetoric from the President that caused a few congressional leaders to register concerns about a possible impulsive move from the White House that could start a nuclear war. ${ }^{14}$ Caveats in this tough US posture included President Trump's avowed unpredictability in the newly fluid situation on the Korean Peninsula in 2018, which led to his remarkable acceptance of a summit meeting with North Korea’s leader in Singapore in June 2018 and another in Hanoi in February 2019. ${ }^{15}$

Regarding US diplomacy and interchange with foreign governments on economic issues - notably the massive American trade deficit with Asia and particularly China - congressional Republican leaders continued to favour free trade. Congressional Democrats, meanwhile, often were associated with proposed government efforts to do more to protect the United States from unfair trade practices of China, as well as some other countries. The Trump government had a hard time formulating a coherent diplomatic approach with Asian governments regarding sensitive economic disputes; administration leaders articulated widely different perspectives, with some favouring a traditional Republican free trade approach and others favouring the approach advocated by candidate Trump of protecting American jobs from China's improper practices.

Where President Trump would come down on this important matter was not clarified by his friendly visit to China in November 2017, followed by a strong declaration against unfair trade during a speech at the APEC Summit attended by the Chinese leader in Hanoi. ${ }^{16}$ The administration's diplomatic line on these issues became more consistent and harder in 2018, and was accompanied by substantial tariffs and investment restrictions which specifically targeted Beijing. Nevertheless, the administration continued negotiations with China, presumably seeking a deal advantageous for the United States.

Disagreements within the administration on economic policy delayed a clear US government strategy towards China and the broader Asia Pacific region. Adding to that problem was the fact that the administration was slow in filling key policy-making positions for China, Korea and other Asian issues, especially 
in the Defense and State departments. The difficulty in selecting qualified staff came in part from the surprising populist upsurge against globalisation and foreign engagement during the 2016 presidential election campaign. This side-lined Republican and Democratic Party elites who supported continued constructive American engagement with the Asia Pacific, rather than the President's emphasis on "America First". Trump's unpredictability in foreign affairs, his demands for intense personal loyalty, and his repeated, public use of vulgar and personal attacks seemed to appeal to his populist base, but most experienced Republican Asian specialists were alienated from the new President. ${ }^{17}$

The Defense Department eventually filled its Asia policy positions, but the departure of Secretary of State Tillerson in March 2018 meant his selected candidate for Asian Assistant Secretary was put aside. The absence of a strong cohort of political appointees in Washington agencies and ambassadors abroad did not prevent Donald Trump from interacting effectively with a wide range of Asian leaders and multilateral inter-governmental groups during his summitry in Washington and his extended trip to Asia in late 2017. And the administration was successful in crafting a coordinated and coherent NSS and NDS. Nonetheless, the absence of diplomatic expertise on North Korea seemed to be a significant weakness as the Trump government prepared for previously unexpected talks with North Korea's leader without the benefit of experienced officials in key positions. It took until July 2018 for the appointments of Trump's ambassador to South Korea and an acting Assistant Secretary of State for East Asian and Pacific Affairs. Trump's US Special Representative for North Korean Policy was appointed the following month.

In general, congressional or other American concern about the absence of a coherent administration policy towards Asia remained the focus of foreign policy specialists concerned with Asian affairs. The crisis over nuclear weapons development in North Korea, beginning in 2017, and tensions caused by tough US tariffs and other economic measures against China in 2018, were high priority issues for the administration, the Congress, the media and non-government organisations dealing with American policy. But they competed for attention with pressing domestic issues including health care reform; tax reform; disaster relief; control of immigration; the role of Russia in influencing US domestic politics and the investigation into possible collusion with the Trump campaign during the 2016 election; and such international issues as the wars in Syria and Afghanistan and the challenges posed by Russian and Iranian assertiveness and expansionism in Europe and the Middle East.

The Trump administration's NSS and NDS provided a well-integrated message for American diplomacy in Asia and the rest of the world. While focused on threats from North Korea, terrorism and Iran, the approach zeroed-in on China and Russia. It employed strong language not seen in authoritative US government commentary on China since before the Nixon administration's opening to China of the early 1970s, to warn in no uncertain terms of China's ambitions to undermine 
US economic, security and political interests and displace the United States and its leadership in the Asia Pacific. It clearly sided with those in the administration seeking a much tougher policy towards China on economic issues.

As already noted, the administration followed through with diplomacy highlighting defence build-ups and economic actions in support of the American strategy. The diplomacy generally meshed with congressional concerns regarding North Korea and China. The United States also began closer collaboration in diplomatic negotiations with Japan, India and Australia to foster military cooperation to secure interests challenged by China in the broader Indo-Pacific region. How far the United States would go in countering perceived adverse Chinese actions throughout the first two years of the Trump administration was determined in part by the region's uncertain priority in the very full international White House agenda. On a personal level, President Trump carried out cordial interchange with Chinese leaders seemingly at odds with the harder approach of his administration's avowed strategy.

\section{Early diplomatic successes}

President Trump's unconventional personal style in foreign affairs added to uncertainty in US relations with China and the broader Asia Pacific region. He strongly opposed President Obama's predictable, transparent and carefully measured policy-making that had been broadly welcomed in the region. The new President favoured unpredictability; he sought advantage in employing dramatic gestures and rhetoric along with military and economic leverage to benefit from resulting tensions, just as he did at the expense of more conventional candidates in his election campaign. Notably, Trump repeatedly inserted himself into the policy process through bluntly worded tweets and other initiatives that exacerbated frictions over important issues both at home and abroad in ways that appealed to his populist constituency, but which upset foreign partners and opponents. ${ }^{18}$

In January 2017, President Trump quickly followed through on his campaign pledge to withdraw from the twelve-nation TPP. Then came the announcement that the Obama government's overall Asian engagement policy known as the Rebalance policy was ended, with little indication of the Trump administration's regional approach. ${ }^{19}$ Both moves reinforced anxiety and dismay among regional allies and partners over the direction of American policy.

The new President's national security leaders, along with Vice President Pence, however, led the administration's reversal of candidate Trump's low regard for American alliances, notably those with Japan, South Korea and Australia. Their travels to the region reassured allies and partners of Washington's security commitments. In June, Secretary Mattis pointedly reassured allies and partners in a measured and strongly-worded affirmation of American support for its security 
commitments in Asia at the annual defence ministers meeting at the Shangri-La Forum in Singapore. ${ }^{20}$ Economic relations remain in question as President Trump continued his complaints about US trade agreements with South Korea and its trade deficits with China and other Asian countries. ${ }^{21}$

\section{North Korea crises and China policy}

North Korea's threatening rhetoric, repeated ballistic missile launches, and nuclear weapons testing saw the early Trump government adopt a more assertive diplomatic approach framed by far more tension than Obama's more moderate and reactive policy of "strategic patience". President Trump and senior administration officials repeatedly warned of unspecified US military options to unilaterally deal with the North Korean threat, while increasing public pressure on China to use its influence to get Pyongyang to halt its nuclear weapons programme. Trump's remarks on China's willingness and ability to get North Korea to stop varied from optimism, to warnings that the United States was prepared to take unilateral military actions. ${ }^{22}$

The crisis over North Korea saw Washington devote careful handling to relations with Beijing. During the campaign, Chinese specialists judged that Trump was a pragmatic businessman who could be "shaped" to align with Chinese interests and would be easier to deal with than Hillary Clinton, had she won the 2016 election. ${ }^{23}$ President-elect Trump up-ended these sanguine views when he accepted a congratulatory phone call from Taiwan's President Tsai Ing-wen in December 2016. When Beijing complained, Trump criticised Chinese economic policies and military advances in disputed islands in the South China Sea, and questioned why the United States should retain support for the One China policy and avoid improved contacts with Taiwan. Trump was eventually persuaded to endorse - at least in general terms - the American view of the One China policy. His informal summit meeting with President Xi Jinping in Florida in early April 2017 went well. The two leaders met again on the side-lines of the G-20 summit in July that year and held repeated phone conversations over North Korea and other issues before Trump's visit to Beijing in November. Despite serious differences between the two countries, both leaders seemed to value their personal rapport, with Xi promising Trump a 'wonderful' visit in China; that remarkable visit prompted the US President's personal gratitude and appreciation. ${ }^{24}$

After the Florida summit, the Trump government kept strong political pressure on China to use its leverage to halt North Korea's nuclear weapons development. Planned arms sales to Taiwan, freedom of navigation exercises in the South China Sea and other US initiatives that might complicate America's search for leverage to stop North Korea's nuclear weapons development were temporarily put on hold. The United States and China also reached agreement on a 100-day action plan to 
further bilateral economic cooperation prior to the first US-China Comprehensive Economic Dialogue, set for July 2017. ${ }^{25}$

The conditionality of Trump's positive stance towards $\mathrm{Xi}$ showed when he registered dissatisfaction with China's efforts on North Korea in June. This was followed by the announcement of arms sales to Taiwan. Freedom of navigation exercises in the South China Sea also went ahead. China responded with routine complaints, and July's economic dialogue produced no agreement on actionable steps to reduce the US trade deficit with China, ending in failure with a cancelled press conference and no joint statement.

Washington opted against harsh economic measures in the lead-up to, and during, the President's trip to China in November 2017. However, Secretary of State Tillerson and Secretary of Defense James Mattis registered the administration's first criticism of China's widely publicised Belt and Road Initiative. The administration also objected to the World Bank's continuing practice of providing a couple of billion dollars a year in development loans to China, and it joined the EU in opposing China's market economy status at the World Trade Organization. ${ }^{26}$ China's uncertainty over the American President also partly explained why, at least temporarily, it avoided controversial expansion in the disputed South China Sea. Beijing also avoided controversial expansions in South China Sea areas claimed by the Philippines because it was seeking to court Philippines President Rodrigo Duterte away from the United States. ${ }^{27}$

\section{Building close ties with Asian leaders}

In the first twelve months of his presidency, Trump made progress in advancing diplomatic, security and economic relations with other important Asian countries. The approach featured summit meetings, even with leaders previously shunned by the United States because of concerns over democracy (e.g. Thailand), human rights (e.g. the Philippines) and corruption (e.g. Malaysia). By and large, these leaders responded positively to the high-level attention by the new American President, which many of them actively sought; they reciprocated with economic concessions and positive treatment of Trump.

Japan's long-serving Prime Minister Shinzo Abe sought a position as the President's closest regional partner. He arranged and attended a remarkable meeting in New York in November 2016 with President-elect Trump. This was followed by a summit in Washington in February 2017 that included a full weekend at the President's Mar-a-Lago resort. The two leaders remained on the same page throughout the tensions over North Korea, though Japan worried about the negative consequences of Trump's abrupt shift towards summitry with North Korea. ${ }^{28}$

On a trip to Indonesia in April 2017, Vice President Pence told officials that Trump would attend the APEC Summit in Vietnam and the US-ASEAN and East 
Asian summits in the Philippines in November. The White House announced the long trip in October that year. Pence's stop to Australia in April 2017 helped to set the stage for a cordial May meeting in New York between Trump and Australian Prime Minister Malcolm Turnbull. The two leaders put aside an earlier heated telephone argument regarding the United States accepting over 1,000 refugees in Australian custody. ${ }^{29}$

In late April 2017, Trump called the leaders of Singapore, the Philippines and Thailand, inviting them to visit the White House. The invitations to the latter two, along with a separate invitation to the Prime Minister of Malaysia, represented a break from the Obama government's arm's-length treatment of these governments, because of concerns over human rights and corruption. The invitations built personal ties with all three leaders that helped to establish toplevel US connections, allowing for President Trump's successful visit to the region and interchange at regional leadership meetings in November 2017.30

Vietnam carried out previously agreed visits to the United States of its senior leaders - the Prime Minister, the Foreign Minister, and the Deputy Defense Minister. Prime Minister Nguyen Xuan Phuc was the first Southeast Asian head of government to meet with President Trump in late May. The Vietnamese premier seemed successful in forging a personal relationship with President Trump. ${ }^{31}$ Newly-inaugurated South Korean President Moon Jae-in travelled to a summit with Trump in late June. He gave top priority to allied cooperation in dealing with the North Korean threat. The South Korean government also followed through with the deployment of Washington's THAAD anti-missile system in South Korea, despite vocal objection from China. ${ }^{32}$

In late June 2017, Indian Prime Minister Narendra Modi was warmly welcomed at the White House. India's importance in neighbouring Afghanistan grew with Trump's decision in August to add 4,000 American troops to the 8,000 stationed in Afghanistan, endeavouring to counter Taliban combatants seeking to overthrow the US-backed Afghan government. Defense Secretary Mattis made his first visit to India in September, with the Pentagon stressing 'US appreciation of India's important contributions toward Afghanistan's democracy, stability, prosperity and security.33

By mid-2017 Malaysian Prime Minister Najib Razak had become mired in a major corruption scandal involving billions of dollars in investment funds that came under investigation by the US Justice Department. Nevertheless, Najib found Washington fully welcoming during a cordial meeting with Trump in September that year. The Trump administration refused to comment on the government investigation. The Malaysian government said it would buy US $\$ 10$ billion in US commercial aircraft over five years, and invest close to US\$ $\$$ billion in the American economy. ${ }^{34}$

The leader of Thailand's 2014 military coup, and resulting Prime Minister Prayuth Chan-ocha, visited the White House with his wife in early October. 
This marked the first such visit by a Thai leader since 2005..$^{35}$ Singaporean Prime Minister Lee Hsien Loong also made a six-day trip to Washington in late October, just prior to Trump's inaugural visit to the region. He promised large purchases of US commercial airplanes and offered advice on China following the Singapore leader's recent talks with Xi Jinping. ${ }^{36}$

Philippines President Rodrigo Duterte's Draconian crackdown on drug traffickers, beginning almost immediately from when he entered office in mid2016, resulted in thousands of extra-legal killings that were strongly criticised by the Obama government and others. The White House put aside such concerns when, in April 2017, Trump invited Duterte to meet in Washington. Duterte demurred but by late September was publicly conciliatory towards the United States before welcoming Trump to the Philippines for talks on bilateral relations and ASEAN related meetings, in his role as chairman of the institution in 2017. ${ }^{37}$

Overall, capping American diplomatic efforts in 2017, the results of the Trump visit to Asia appeared successful. Familiar with Trump because of earlier cordial meetings in the United States, important Asian leaders were attentive and solicitous, seeking improved relations. The American President's concerns about the threat from North Korea, US trade imbalances, and other economic complaints were evident throughout. While Trump continued to reject multilateral economic agreements, he participated fully in the APEC and US-ASEAN summit. ${ }^{38}$ The President's attentiveness throughout his remarkably long and demanding schedule in the region signalled strong top-level US commitment of continued active engagement in regional affairs. There was little in the trip for administration critics in the United States or elsewhere to complain about. ${ }^{39}$

\section{Recent developments, uncertain strategy}

President Trump's 2017 activism in Asia was not repeated in 2018. North Korea and China got high-level attention, but other regional priorities received more episodic treatment. Developments showed some clear and consistent elements of American strategy, notably on defence and in a diminished American profile on human rights, democracy and promotion of good governance..$^{40}$ Trump's dramatic move towards summitry with North Korea came in close consultations with leaders of South Korea and Japan. South Korean President Moon Jae-in played an instrumental mediating role between Trump and Kim Jong-un before the TrumpKim summit in Singapore on 12 June, and in managing US-North Korean disputes that followed. President Trump also praised China's role in facilitating the summit.

Apart from the Singapore trip in June, however, Trump did not travel to Asia; and he avoided the diplomatic bonhomie that characterised his 2017 trip to the region and his meetings with Asian leaders in Washington and Florida. $\mathrm{He}$ overrode differences among his senior leaders on trade policy to launch punitive 
tariffs and political pressure on various Asian and other partners, to compel changes in economic relations advantageous to the United States. South Korea agreed to a revised free trade agreement with the United States, and Japan agreed to talks on a bilateral trade accord. These came in tandem with US pressure on trade with Mexico and Canada, leading to the conclusion of a new trade agreement to replace NAFTA, which Trump had long criticised.

China received the lion's share of administration pressure on trade and it responded in kind. The trade war was accompanied by the Trump government targeting Chinese policies and practices on a wide range of economic, political and security issues, bringing relations to their lowest point in decades. The US hardening on China was in line with the administration's declared national security strategy.

In Asia, administration officials began to flesh out the contents of their avowed Indo-Pacific strategy which showed a clear focus on China as the prime US concern. In June 2018, Secretary of Defense James Mattis described the Trump administration's emerging Indo-Pacific strategy as deepening alliances and partnerships, stressing that ASEAN remained central to regional stability, and affirming openness to cooperation with China 'wherever possible. ${ }^{41}$ In August, Secretary of State Mike Pompeo announced nearly US $\$ 300$ million in new US funding to strengthen maritime security, develop humanitarian assistance and peacekeeping capabilities, and enhance programmes that counter transnational threats.

Trump also highlighted a US\$113 million fund that will promote publicprivate partnerships as a down payment on a larger project to reorganise and rationalise the US development aid bureaucracy to be better able to mobilise and guide private-sector capital. This project, manifest in the Better Utilization of Investments Leading to Development (BUILD) Act, passed by Congress and signed by the President in October, more than doubled the US government's development-finance capacity, to US $\$ 60$ billion, in order to support US private investment in strategic opportunities abroad. These measures complemented efforts by Japan, Australia and India, often in cooperation with the United States, to provide funding for infrastructure and investment needed in the Indo-Pacific in competition with China's expansive international infrastructure, lending and investment in the so-called Belt and Road Initiative.

Despite such measures, regional officials looked in vain for a coherent American strategy. Indeed, in March 2019 the US Government Accountability Office released a report which pointed to staff shortages in key positions of the foreign services. While comparable to shortages of previous years, it noted that the highest proportion of vacancies were for posts related to South Asia. Staff in East and South Asia reported 'that vacancies in these sections had limited their capacity to engage with host government officials on important, strategic issues.'2 
Unlike the discipline that characterised the carefully crafted discourse and prudent behaviour of the Obama government in support of its Rebalance policy in Asia, the Trump administration's initiatives have, to date, been replete with uncertainties and ambiguities. Notably, the avowed tougher US government approach to China contained caveats including ongoing negotiations with China, Trump's positive personal relationship with his Chinese counterpart, and his avoidance of the type of tough rhetoric against China seen in the National Security Strategy. Perhaps of most importance has been Trump's avowed unpredictability, which led to his two summit meetings with North Korea's Kim Jong-un in 2018 and 2019 and which could allow for top-level deal making over key differences with China that would belie the stated administration strategy.

In sum, the deliberative and moderate approach of Barack Obama's Rebalance policy has, in the first two years of the Trump administration, been put aside in favour of a still ill-defined approach of the much more flamboyant and unpredictable Donald Trump. The Trump government shows in spades its willingness to apply power against those it opposes - a perceived weakness in Obama's approach to China. It has used the wide range of economic, diplomatic and military power available to the American superpower. The consequences of the policy shift are wearing on American allies and partners. Evaluating their overall impact will need to take account of the results of the policy shift, which are only vaguely evident at present and subject to be overtaken by unexpected moves by the US President or others.

\section{Notes}

1 J. Tankersley, 'Trump's Tariffs Keep Allies and Industry Apprehensive', New York Times (26 March 2018), p. B1.

2 A. Panda, 'The “Pivot' to Asia Is Over', The Diplomat (14 March 2017), https:// thediplomat.com/2017/03/straight-from-the-us-state-department-the-pivot-to-asiais-over/, accessed 12 March 2018.

3 H. Meijer (ed.), Origins and Evolution of the US Rebalance toward Asia: Diplomatic, Military and Economic Dimensions (London: Palgrave Macmillan, 2015); K. Campbell, The Pivot: The Future of American Statecraft in Asia (New York: Twelve, 2016).

4 R. Sutter, China-US Relations, 3rd edition (Lanham, MD: Rowman \& Littlefield, 2018), pp. 151-9.

5 See among others, L. Hadar, 'Obama's West Point Realism', The American Conservative (30 May 2014), www.theamericanconservative.com/articles/obamaswest-point-realism/, accessed 12 March 2019.

6 W. Lohman, 'Top Five Political-Security Priorities for the Asia Pacific in 2016', Heritage Foundation (5 February 2016), www.heritage.org/asia/report/top-fivepolitical-security-priorities-the-asia-pacific-2016, accessed 23 October 2019. 
7 R. Sutter and S. Limaye, 'America's 2016 Election Debate on Asia Policy and Asian Reactions', East-West Center (2016), pp. 6-7.

8 Ibid., p. 7.

9 J. Martin and A. Burns, 'Donald Trump's Slip in Polls has GOP Worried About Congress', New York Times (5 October 2016), www.nytimes.com/2016/10/06/us/ politics/donald-trump-campaign.html, accessed 12 March 2019.

10 Sutter and Limaye, 'America's 2016 Election Debate', pp. 7-8.

11 White House, 'National Security Strategy of the United States' (December 2017), www.whitehouse.gov/wp-content/uploads/2017/12/NSS-Final-12-18-2017-0905. pdf, accessed 12 March 2019; US Department of Defense, 'Summary of the National Defense Strategy of the United States' (January 2018), www.defense. gov/Portals/1/Documents/pubs/2018-National-Defense-Strategy-Summary.pdf, accessed 12 March 2019.

12 R. Delaney, 'China Offers Trump US $\$ 200$ Billion Cut in Trade Surplus', South China Morning Post (18 May 2018), www.scmp.com/news/china/diplomacydefence/article/2146660/us-president-donald-trump-meet-chinese-vice-premierliu, accessed 12 March 2019.

13 A. Macias, 'Defense-Friendly Spending Bill', CNBC (22 March 2018), www.cnbc. com/2018/03/22/defense-friendly-spending-bill-big-for-military.html, accessed 12 March 2019.

14 K. Demirjian, 'Trump's Nuclear Authority Divides Senators "Alarmed” by his Volatile Behavior,' Washington Post (14 November 2017), www.washingtonpost. com/powerpost/senators-deadlock-in-debate-over-whether-to-restrain-trumpsnuclear-launch-authority/2017/11/14/491a994a-c95b-11e7-8321-481fd63f174d_ story.html, accessed 12 March 2019.

15 BBC, 'North Korea Summit' (18 May 2018), www.bbc.com/news/worldasia-44158566, accessed 12 March 2019; New York Times, 'Trump-Kim Summit: Leaders Have Dinner in Vietnam' (26 February 2019), www.nytimes. com/2019/02/26/world/asia/trump-kim-summit-vietnam.html, accessed 14 March 2019.

16 R. Sutter, 'The United States and Asia in 2017', Asian Survey, 58:1 (2018), pp. $10-20$.

17 D. Steinberg, 'Trump Administration Alienates Asia Hands', Nikkei Asian Review (1 April 2017), https://asia.nikkei.com/Viewpoints/David-I.-Steinberg/Trumpadministration-alienates-Asia-hands-at-America-s-peril, accessed 12 March 2019.

18 R. Sutter, 'Trump and China', East Asia Forum Quarterly, 9:2 (2017), pp. 121-8.

19 Panda, 'The "Pivot" to Asia Is Over'.

20 P. Parameswaran, 'What Mattis' Shangri-La Dialogue Speech Revealed', The Diplomat (6 June 2017), https://thediplomat.com/2017/06/what-mattis-shangri-ladialogue-speech-revealed-about-trumps-asia-policy/, accessed 12 March 2019.

21 Ibid.

22 P. Baker and D. Sanger, "Trump Says Tillerson is "Wasting his Time" on North Korea, New York Times (1 October 2017), www.nytimes.com/2017/10/01/us/ politics/trump-tillerson-north-korea.html, accessed 12 March 2019. 
23 Sutter and Limaye, 'America's 2016 Election Debate', p. 21.

24 Sutter, 'The United States and Asia in 2017', p. 12.

25 B. Glaser and C. Norkiewicz, 'North Korea and trade dominate the agenda', Comparative Connections, 19:2 (2017) pp. 21-34

26 Sutter, 'The United States and Asia in 2017', p. 13.

27 R. Sutter and C. Huang, 'Steady gains in the South China Sea', Comparative Connections, 19:2 (2017), pp. 53-62.

28 Y. Tatsumi, 'Trump Meets Abe: Beyond the Publicity', The Diplomat (8 November 2017), https:/thediplomat.com/2017/11/trump-meets-abe-beyond-the-publicity/, accessed 12 March 2019.

29 L. Figueroa, 'President Trump Meet Australian PM', Newsday (4 May 2017), www. newsday.com/news/new-york/president-donald-trump-returns-to-ny-meetsaustralian-pm-1.13563086, accessed 12 March 2019.

30 Sutter, 'Trump and China'.

31 M. Landler, 'Trump Hosts Prime Minister Phuc of Vietnam', New York Times (31 May 2017), www.nytimes.com/2017/05/31/world/asia/vietnam-nguyen-xuanphuc-trump.html, accessed 12 March 2019.

32 C. E. Lee, W. Mauldin and E. Stokols, 'Trump and South Korea's Moon Assert Unity Against North Korea, Wall Street Journal (30 June 2017), www.wsj.com/ articles/trump-meets-south-koreas-moon-jae-in-calls-for-new-trade-deal1498836731 , accessed 12 March 2019.

33 H. Pant, 'Mattis Comes to India: What's on the Agenda', The Diplomat (26 September 2017), https://thediplomat.com/2017/09/mattis-comes-to-india-whatson-the-agenda/, accessed 12 March 2019.

34 W. S. Wan, 'Why Najib's Washington Visit Was a Success', New Straits Times (17 September 2017), www.nst.com.my/opinion/columnists/2017/09/280743/whynajibs-washington-visit-was-success, accessed 12 March 2019.

35 R. Ehrlich, 'White House Meet Legitimates Thailand's Strongman Rule', Asia Times (1 October 2017), www.atimes.com/article/white-house-meet-legitimatesthailands-strongman-rule/, accessed 12 March 2019.

36 Xinhua, 'Good US-China Relations Benefit Region, World: Singapore PM' (24 October 2107), http://en.people.cn/n3/2017/1024/c90000-9284064.html, accessed 12 March 2019.

37 K. Phillips, 'Philippines Duterte Vows Not to Come to the US', Washington Post (22 July 2017), www.washingtonpost.com/news/worldviews/wp/2017/07/22/ philippines-duterte-vows-to-not-come-to-the-u-s-ive-seen-america-and-its-lousy/ ?utm_term=.30c9ee0a66cf, accessed 12 March 2019; New York Post, 'TrumpDuterte Have Cordial First Meeting' (11 November 2017), https://nypost.com/ 2017/11/11/trump-duterte-have-cordial-first-meeting-at-apec-summit/, accessed 12 March 2019.

38 Guardian, 'Donald Trump Skips East Asian Summit' (14 November 2017), www. theguardian.com/us-news/2017/nov/14/donald-trump-skips-east-asia-summiton-final-day-of-12-day-tour, accessed 12 March 2019. 
39 For coverage and details on the various stops and activities during the visit, see relevant articles in Comparative Connections, 19:3 (2018).

40 See R. Sutter, 'The United States and Asia in 2018', Asian Survey, 59:1 (2019).

41 US Department of Defense, 'Remarks by Secretary Mattis at Plenary Session of the 2018 Shangri-La Dialogue' (2 June 2018), https://dod.defense.gov/News/ Transcripts/Transcript-View/Article/1538599/remarks-by-secretary-mattis-atplenary-session-of-the-2018-shangri-la-dialogue/, accessed 18 March 2019.

42 US Government Accountability Office, 'Integrated Action Plan Could Enhance Efforts to Reduce Persistent Overseas Foreign Service Vacancies' (March 2019), p. 18. 